\title{
An Examination of Household Poverty Affecting Food Insecurity in Turkey (Muş Province)
}

\author{
Associate Prof. Dr. Seher ERSOY QUADIR \\ Necmettin Erbakan University, Faculty of Health Sciences, \\ Department of Social Work, Konya, Turkey \\ E-mail: seherers@gmail.com \\ Associate. Prof. Dr. Didem ÖNAY DERIN \\ Selcuk University, Faculity of Health Sciences, \\ Department of Nutrition and Dietetics, Konya, Turkey \\ E-mail: donay@selcuk.edu.tr \\ Assistant. Prof. Dr. Mehmet AKMAN \\ Mevlana University, Faculity of Health Sciences, \\ Department of Nutrition and Dietetics, Konya, Turkey \\ E-mail:makman@mevlana.edu.tr
}

Received: July 14, 2014 Accepted: October 1, 2014 Published: October 29, 2014

doi:10.5296/jsss.v2i1.6522 URL: http://dx.doi.org/10.5296/jsss.v2i1.6522

\begin{abstract}
Quality of life in a society depends on the extent to which people's basic needs have been met. Having access to foodstuff is one of the basic human needs. Following globalization in the second half of the 20th Century, although the level of affluence is claimed to have increased all over, inadequacy of food and its access, is not only a problem in underdeveloped countries, but also in developed and developing countries. This study attempts to determine the extent of food insecurity in Turkey, which is considered a developing country. With this aim in mind, the study was carried out on households in Malazgirt county of Muş province and its villages
\end{abstract}


in the Eastern Anatolia region, where poverty is very intensely experienced (both in urban and rural areas). In order to collect data, "United States Household Food Insecurity Access Scale" (HFIAS) was used. Based on this study, $71.0 \%$ of the sample group accepts "extreme hunger food insecurity" rarely, 16.8\% accepted "partial hunger food insecurity" rarely and $12.2 \%$ frequently accepted "slight (without hunger) food insecurity". In this study, the relation between food insecurity was also examined. It was determined that women accepted food insecurity without hunger $(p<0.001)$ and with partial hunger $(p<0.01)$ more compared to males. It was found that food insecurity was strongly related to all income levels $(p<0.001)$. On the other hand, monthly food expense was partially related $(p<0.05)$ with hunger. It was determined that food insecurity with extreme hunger was experienced more intensively as the number of household increased $(\mathrm{p}<0.05)$.

Keywords: Poverty, Food insecurity, Household

\section{Introduction}

Food security is a situation that exists when all people, at all times, have physical, social and economic access to sufficient, safe and nutritious food that meets their dietary needs and food preferences for an active and healthy life (FAO, 2003). From a broader point of view, food poverty can be considered not only as meeting mere physical requirements assessed on the basis of minimal cost of living but also means accessing or consuming socially acceptable amount and quality of food (Dowler, 2003).

"Food insecurity" is synonymous to "food poverty" and results from physical inadequacy of food, socioeconomic poverty in having access to adequate amount of food or from inadequate intake of food (Gutherie \& Nord, 2002; Chenoweth, 2007). Therefore, families with no purchasing power and with inadequate income suffer from malnutrition problems, which prevents the society from leading a healthy life with a capacity to work and increase economic and social wealth (Kocakayta, 2007). Therefore, food insecurity is considered as a part of the concept of poverty; moreover, it is seen as the fundamental factor in poverty. The World Bank and Turkish Institute of Statistics (TÜIK) categorize lacking income level to afford even basic needs as absolute poverty, and having difficulty in meeting social needs (public transportation, health, education and cultural activities) as relative or humanistic poverty (Sallan-Gül, 2002; Ensari, 2010). The number of child and adult poor individual is 1 billion 200 million all over the world, this means that one out of five people around us is poor. Besides, all over the world, 47 million of 600 million children who live under the poverty threshold are in OECD (Organization for Economic Co-operation and Development) countries (total 33 countries). Among OECD countries relative poverty rate is $26.2 \%$ in Mexico, $22.4 \%$ in the U.S., $20.5 \%$ in Italy, $19.8 \%$ in the UK and $19.7 \%$ in Turkey. Besides, in developing countries 200 million children younger than age 5 struggle to live under absolute poverty threshold (World Children of the New Millennium on World Children's Day: Numerical Children Warning Report, 2011). Therefore, under-nutrition and malnutrition are important wealth and health problems not only in underdeveloped countries with high population but also in developing and developed countries alike at a slightly different level.

The current study emphasizes several criteria that determine absolute poverty level, which symbolizes food insecurity. According to the first criterion, absolute poverty is calculated based on daily minimum calorie needs. In this case, the calculation is based on the amount of 
calories (2800-3000 k/cal which depending on the characteristics of work increases up to $3200-3800 \mathrm{k} / \mathrm{cal}$ for those performing hard labour) an adult needs to take daily and those who cannot afford to buy $2350 \mathrm{k} / \mathrm{cal}$ of food with their daily income are identified as suffering from "absolute poverty" (Avşar Kurnaz, 2007; Caldwell et al., 2011). However, this amount can change according to socio-economic structures and geographical conditions of countries. In developed countries it is 3390 calories, in developing countries it is 2480 calories and in underdeveloped countries it is calculated as 2070 calories. These amounts are calculated based on the means of annual food prices in the currency of the country and the poverty thresholds (Kalınkara, 2011).

The second criterion that determines absolute poverty is the size of the family and the lowest amounts of goods and services to be consumed. The third criterion is the price of goods and services which determines the amount of expenses required to fulfil the needs. Based on these, poverty threshold is a certain amount of money expressed in a particular currency. Therefore, those earning less than poverty threshold are classified as poor and those who earn more than this amount are categorized as not poor. (Öztürk \& Çetin, 2009). Concordantly, between the years 1981 and 2001 the World Bank indentified those whose daily income was less than \$2 as relatively poor and those who earn less than $\$ 1$ a day were considered absolutely poor (below the poverty threshold) (World Bank, 2001). The absolute poverty level calculations were determined based on $\$ 1.25$ for the years between 2005 and 2020 (Arpacioğlu \& Y1ldirım, 2011). The mentioned threshold can vary depending on the development level of the country. For example, this threshold is determined to be \$2 for Latin America and Philippines, $\$ 4$ for the group which includes the Eastern European countries and Turkey, as well, and $\$ 14.40$ for developed industrial countries (DPT, 2001).

Besides, although the absolute poverty level is determined based on the amount of calories in daily diet, the quality and diversity of food in the diet are also indicators of whether people eat a healthy and adequate diet. The cheapest sources of calories for consumers are fats and carbohydrates. If just meeting energy requirements would be sufficient to lead a healthy life, people would be able to get sufficient amount of food with less than $\$ 1$ a day. However, vegetables, milk products, meats and fruits are the healthiest groups of food and people need to spend more than $\$ 20$ a day for a sufficient diet (Finke et al., 1996).

As the amount of income decreases, families' purchasing power to buy meat, chicken, fish, milk and dairy products and even legume which are rich in protein, group B vitamins, iron, zinc and calcium decreases. Not taking adequate amounts of protein, carbohydrates, vitamin and minerals regularly leads to lassitude, fatigue, concentration disorder and some temporary and permanent diseases. Besides, given that brain development starts in the fetal period and continues to develop fastest in the first three years after birth, not taking iodine, iron, zinc, folic acid, vitamin $\mathrm{B}_{12}, \mathrm{~B}_{6}, \mathrm{E}$ and $\mathrm{A}$ and essential fatty acids adequately increases the risk of giving birth to mentally impaired children (Baysal, 2003).

As a matter of fact, in a study by Jensen and Manrique (1998) in which they examined the food demand levels of the household of different income levels in the rural parts of Indonesia, it was determined that household with low income could not frequently afford to buy milk and dairy products and could never buy meat and meat products. Moreover, it was also found that compared to other income groups they tended to purchase more of rice and fish 
comprising the second level food group. In another study carried out in Bangladesh, within the scope of a project developed to decrease poverty in the years 2002-2004-2006 (CFPR: Challenging the Frontiers of Poverty Reduction), initially the most disadvantaged group was determined. With the aids provided, it was determined that the diets of beneficiaries did not only include more food varieties but also included significant amount of food of animal origin. Apart from that, total energy and protein intake increased as well (Haseen \& Sulaiman, 2007). These cases indicate that as the income levels of people rise, their opportunities to eat adequate and healthy food also increase.

\subsection{Estimations of Food Insecurity in Turkey}

Thanks to the economic development in the last 15 years, Turkey is now the $16^{\text {th }}$ largest economy in the world. According to household budget survey data from 1994 and 2003, it was determined that the share of food expenses within the income decreased during this period. In other words, it was found that purchasing power of the people increased with increasing income (Kalyoncu, 2009). Daily purchase indicator per person in the poverty research by TUIK (Turkish Statistics Institution) between 2002 and 2009 reflects a similar situation. While the rate of people whose daily purchasing power per person is lower than $\$ 2.15$ was $3.04 \%$ in 2002 this rate was estimated to be $0.22 \%$ in 2009 (Table 1). Based on $\$ 4.3$ poverty threshold, the 2002 poverty rate decreased from $30.30 \%$ to $4.35 \%$ in 2009 (TÜİK, 2012a).

Table 1. Individual poverty rates based on poverty threshold methods in Turkey 2002-2009 (TÜİK, 2008; TÜİK, 2010; TÜİK, 2012a)

\begin{tabular}{|c|c|c|c|c|c|c|c|c|}
\hline \multirow{2}{*}{$\begin{array}{l}\text { Poverty } \\
\text { Threshold Methods }\end{array}$} & \multicolumn{8}{|c|}{ Individual Poverty Rate, Global (\%) } \\
\hline & 2002 & 2003 & 2004 & 2005 & 2006 & $2007(*)$ & 2008 & 2009 \\
\hline Food poverty (hunger) & 1.35 & 1.29 & 1.29 & 0.87 & 0.74 & 0.48 & 0.54 & 0.48 \\
\hline Poverty (food + non-food) & 26.96 & 28.12 & 25.60 & 20.50 & 17.81 & 17.79 & 17.11 & 18.08 \\
\hline $\begin{array}{l}\text { Less than } \$ 1 \text { a day per } \\
\text { person }\end{array}$ & 0.20 & 0.01 & 0.02 & 0.01 & 3.4 & 3.4 & 3.4 & 2.7 \\
\hline $\begin{array}{l}\text { Less than } \$ 2.15 \text { a day per } \\
\text { person }\end{array}$ & 3.04 & 2.39 & 2.49 & 1.55 & 1.41 & 0.52 & 0.47 & 0.22 \\
\hline $\begin{array}{l}\text { Less than } \$ 4.3 \text { a day per } \\
\text { person }\end{array}$ & 30.30 & 23.75 & 20.89 & 16.36 & 13.33 & 8.41 & 6.83 & 4.35 \\
\hline $\begin{array}{l}\text { Expense based relative } \\
\text { poverty (1) }\end{array}$ & 14.74 & 15.51 & 14.18 & 16.16 & 14.50 & 14.70 & 15.06 & 15.12 \\
\hline
\end{tabular}

(*) From the year 2007onwards, new population projections are used.

(1) Equivalent consumption per person was based on 50 per cent of median value.

As shown in Table 2 below, although there has been decrease in individual poverty rates, there is an obvious inequality in income distribution. As of 2011, Turkish population were 
grouped into five based on household income and while the share of the last group, which has the highest income, was $46.7 \%$ of the total income, the rate the lowest group received from total income was $5.8 \%$. Accordingly, the share of the highest 20 percent group is 8 times as much as the share of the lowest 20 percent group (Table 2). Besides, according to accommodation units the Gini coefficient was estimated to be 0.404 (TÜİK, 2012b). When the Gini rate is closer to 1 , the inequality between accommodation units increased and the inequality decreased as the rate gets closer to 0 . In this case, Turkey is to be considered as a country with serious levels of inequalities. The results of the study by Oğuz et al. (2012) in which they examined income distribution in agricultural enterprises in Konya province supports the mentioned inequality. The Gini rate among the examined catchment areas was found to be 0.50 for the Central Anatolia agricultural plain, 0.52 for Inner Aegean Agricultural plain and 0.57 for the Lakes Region agricultural plain.

Table 2. Order of annual household disposable income distribution (quintiles) in Turkey, 2010-2011 (TÜİK, 2012b)

\begin{tabular}{lrrrrrrr}
\hline \multirow{2}{*}{ Quintiles Individual Groups } & \multicolumn{2}{c}{ Turkey } & \multicolumn{2}{c}{ Urban } & \multicolumn{2}{c}{ Rural } \\
& $\mathbf{2 0 1 0}$ & $\mathbf{2 0 1 1}$ & $\mathbf{2 0 1 0}$ & $\mathbf{2 0 1 1}$ & $\mathbf{2 0 1 0}$ & $\mathbf{2 0 1 1}$ \\
\hline Total & 100.0 & 100.0 & 100.0 & 100.0 & 100.0 & 100.0 \\
The first quintile ${ }^{(*)}$ & 5.8 & 5.8 & 6.3 & 6.2 & 6.2 & 6.1 \\
The second quintile & 10.6 & 10.6 & 11.0 & 10.8 & 11.0 & 10.9 \\
The third quintile & 15.3 & 15.2 & 15.3 & 15.2 & 15.7 & 15.7 \\
The fourth quintile & 21.9 & 21.7 & 21.6 & 21.5 & 22.8 & 22.5 \\
The last quintile ${ }^{(*)}$ & 46.4 & 46.7 & 45.7 & 46.2 & 44.3 & 44.8 \\
Gini coefficient & 0.402 & 0.404 & 0.389 & 0.394 & 0.379 & 0.385 \\
The last quintile / The first quintile (P80/ 20) & 8.0 & 8.0 & 7.3 & 7.4 & 7.1 & 7.4 \\
\hline
\end{tabular}

Not: Incomes reference periods are the previous calendar year.

(*) Individuals are designated in ascending order based on equivalent household disposable incomes in 5 groups, "The first quintile group" is the group with the lowest income; "The last quintile group" defines the group with the highest income.

The difference among socio-economic groups in question is more marked in the lower income groups; it is also seen in the "Multidimensional Poverty Index" which the United Nation started to use instead of the human poverty index since 2010. According to this index, $0.21 \%$ of the population live with a daily income less than $\$ 2.15,2.6 \%$ of the population live with daily income lower than $\$ 1.25$. Therefore, when we speak of inequality in income distribution in Turkey, we can mention inequality not only between high and low level but also between low and middle income level (Kizılaslan et al., 2012).

Besides, inequality of income distribution in Turkey varies depending on the region and on the size of residential area. It was seen that the absolute and relative poverty rates had been 
higher in the Black Sea, the Eastern Anatolia and the Southeastern Anatolia Regions (Günindi Ersöz, 2003; Çabuk Kaya, 2006; Koç \& Gül, 2006). It was also found that there were regional differences between average incomes of waged workers. For example, according to the results of 2010 Income Structure Survey (ISS), the average gross income is the lowest in the Southeastern Anatolia region (Demir Şeker \& Küçükbayrak, 2012). According to the recent data, $30 \%$ of the children in the Eastern Anatolia face chronic malnutrition and extreme emaciation, which was found to be $10 \%$ in the West (World Children of the New Millennium on World Children's Day: Numerical Children Warning Report, 2011). Therefore, the developmental differences between regions and provinces and increasing poverty cause the isolation of large groups of people from economic, political and social life. This leads to increasing difference between the rich and the poor in terms of life standard, social polarization and the spread of the feeling of "hopelessness" among disadvantaged groups (Günindi Ersöz, 2003).

In this case, the existence of our citizens who have to survive with money below poverty and hunger threshold cannot be denied. As a matter of fact, according to TÜİK (2011b) data, $16.9 \%$ of the population is under the risk of poverty, the rate of those under constant risk of poverty is $18 \%$, which means a population of 13.2 million. Thus, among the OECD countries, Mexico has the largest poor population, which is followed by the US and Turkey, respectively (Saner et al., 2012).

Therefore, in this study, our aim is to determine the food insecurity level of vulnerable people who live below normal conditions in Turkey. Thus, the study was carried out in the city center and villages of Malazgirt county of Mus province, which is located in the Eastern Anatolian Region where poverty is experienced very heavily (both in the rural and urban area). The food insecurity feeling levels were examined in terms of their gender, age, amount of income and the number of family members.

\section{The Method and Means of Study}

\subsection{The Scope and Sample of the Study}

The population sample of the study comprised of the parents of the students from 28 different close villages attending regional primary boarding school in Malazgirt county of the relatively poor Muş province (located in the Eastern Anatolia Region of Turkey) in 2010. Parents of 345 students who were randomly chosen among the students at the school constituted the sample of the study.

\subsection{Means of Data Collection (Study Design: Survey Instrument)}

The study was designed in the general survey model. The questionnaire technique was used to obtain data for the study. The questionnaire forms distributed to 345 students who were chosen with random sampling method were filled in by their parents. In the questionnaire, apart from the questions to determine demographic characteristics of the participants, United States Household Food Insecurity Access Scale (HFIAS) which was developed by Coates et al. (2007) was used to determine their food insecurity levels (Table 3). The 9-item scale shown in Table 3 was adapted from an 18 item questionnaire which was developed and administrated to the whole public by researchers at Economic Research Service (ESR) at the United States Department of Agriculture in 1995 to determine food security of American 
household. With this scale, a series of questions were directed to individuals about their experiences and behaviors in order to classify household according to their difficulties in meeting food needs (Gutherie \& Nord, 2002). The questions in the questionnaire had agree (Yes) or disagree (No) options. Those who accepted to have food insecurity were further asked about the frequency they experienced this insecurity. To determine the severity of food insecurity, frequency levels were scaled as follows: 1= "Rarely" (once or twice in the last four weeks), 2= "Sometimes" (three to ten times over the last week) and 3= "Frequently" (more than four times over the last week). If the questionnaire is intended to measure food insecurity over a year, it is to be repeated for 12 months and aggregations are to be taken for each question separately. Since this study was carried out to determine the situation in a limited area, food insecurity data for a month were used.

Table 3. Adapted U.S. household food security survey module (US HFSSM) ${ }^{1}$ 1 Were you worried that your food would run out before you had money to buy more?

\begin{tabular}{l}
\hline A) Yes B) No-Go to question $2^{2}$ \\
1a How often did this occur? ${ }^{3}$ \\
1) Often 2) Sometimes 3) Rarely \\
2 If the food you had didn't last, did you not have enough money to buy more? \\
3 Did you have to eat the same foods daily because you did not have money to buy \\
other foods?
\end{tabular}

4 Have you or any other adult in your household cut the size of your meals because you did not have enough money to buy food?

5 Did you skip some of your daily meals because you did not have enough money for food? $^{4}$

6 Did you ever eat less than you felt you should because you did not have enough money to buy food?

7 Were you ever hungry and did not eat because you did not have money to buy enough food?

8 Did you lose weight because you did not have enough money to buy food?

9 Did you or another adult in your household ever not eat for a whole day because you did not have enough money to buy food?

${ }^{1}$ Time frame of reference for all the questions was the last 12 months.

${ }^{2}$ All questions had this response format.

${ }^{3}$ Follow-up question applied to all questions excepting question 8.

${ }^{4}$ Daily meal: breakfast, lunch, tea or dinner.

\subsection{HFIAS Reliability}

As a result of statistical analysis with regard to the reliability of HFIAS, the reliability of the scale was calculated to be Alpha $=0.796$. This value indicates that the scale has a good reliability level. 
2.4 Data Analysis

In this study, first, the level of household food insecurity participants accepted were interpreted after tabulation according to mean scores. Besides, Pearson Correlation Coefficient was calculated in order to determine whether individuals' food insecurity acceptance levels were related to each other and related with demographic variables (gender, age, monthly income, monthly food expense and the number of household).

\subsection{Demographic Features of the Sample Group}

Exactly $59.4 \%$ of the individuals in the study were female, $40.6 \%$ were male. More than half of the sample were $(67.0 \%)$ primary school graduates or less educated. Besides, $37.4 \%$ of the participants were aged between $31-40$ ages, $35.9 \%$ were 41 years old and over, $26.7 \%$ were 30 years old and less. The number of individuals in the household were 6 to 8 in $35.6 \%$ and $35.1 \%$ of the household included 9 and more people. Monthly household total income ranged between 301-600 TL for 39.1\%, 38.3\% earned $300 \mathrm{TL}$ and more and 22.6\% had $601 \mathrm{TL}$ and more monthly income (Table 4). 
Table 4. Demographic characteristics of the sample $(n=345)$

\begin{tabular}{|c|c|c|}
\hline Gender & $\mathbf{n}$ & $\%$ \\
\hline Female & 205 & 59.4 \\
\hline Male & 140 & 40.6 \\
\hline \multicolumn{3}{|l|}{ Education Level } \\
\hline Primary school graduates or lower & 231 & 67.0 \\
\hline Secondery school graduates & 80 & 23.2 \\
\hline High school and equivalent graduates & 27 & 7.8 \\
\hline University graduates or higher & 7 & 2.0 \\
\hline \multicolumn{3}{|l|}{ Age } \\
\hline 30 years old and less & 92 & 26.7 \\
\hline Between 31 to 40 ages & 129 & 37.4 \\
\hline 41 years old and over & 124 & 35.9 \\
\hline \multicolumn{3}{|c|}{ The number of individuals in the household } \\
\hline 5 or less & 101 & 29.3 \\
\hline Between 6 to 8 & 123 & 35.6 \\
\hline 9 or more & 121 & 35.1 \\
\hline \multicolumn{3}{|l|}{ Monthly household total income (TL*) } \\
\hline 300 and less & 132 & 38.3 \\
\hline Between 301to 600 & 135 & 39.1 \\
\hline 601 and over & 78 & 22.6 \\
\hline \multicolumn{3}{|c|}{$\begin{array}{l}\text { The amount of income allocated to monthly household } \\
\text { food expenditure (TL) }\end{array}$} \\
\hline 100 and less & 106 & 30.7 \\
\hline Between 101 to 250 & 114 & 33.1 \\
\hline 251 and over & 125 & 36.2 \\
\hline \multicolumn{3}{|c|}{ Household food expenditures income ratio } \\
\hline $40 \%$ and less & 124 & 35.9 \\
\hline Between $41 \%$ to $60 \%$ & 121 & 35.1 \\
\hline $61 \%$ and over & 100 & 29.0 \\
\hline
\end{tabular}

* 1 TL was 1.57 \$ in 2010 in Turkey.

According to the results of the "hunger and poverty threshold" research which has been continually carried out monthly by Confederation of Turkish Trade Unions (TURK-IS) for 23 years, the poverty threshold for four person family was determined to be $2801.88 \mathrm{TL}$ (1784,64 \$) in October 2010 and hunger threshold was 860.18 TL (547.89 \$) (Hunger and Poverty Threshold, 2010). The minimum wage was determined to be 599.12 TL (381.60 \$) for the same period (MuhasebeBlog, 2014). Following from the data, when the income distribution of the sample group with 6 or more household number was examined, it was seen that $98.8 \%$ of the household $(n=341)$ had income below poverty threshold, $89.9 \%(n=310)$ had income lower than hunger poverty, and $77.4 \%$ has $(n=267)$ had income lower than 
minimum wages. Oğuz et al. (2012) attempted to measure the severity of poverty by interviewing 713 households living in 170 villages of Konya province in the Central Anatolia region of Turkey. Based on individual poverty threshold which was determined to be $\$ 899.67$ for a month, by Turkish Statistic Institution for the year 2009, the sample group was classified as follows: $36.80 \%$ poor, $49.38 \%$ normal and the remaining $13.82 \%$ was classified as rich. This result indicates that food insecurity in the rural of the Central Anatolia Region of Turkey is not as severe as it is in the Eastern Anatolia Region, which is studied here.

As shown in Table 4, the highest amount allocated for food expenses was found to be $251 \mathrm{TL}$ and more (36.2\%) and the least was (30.7\%) 100 TL and lower. 35.9\% of the household allocated $40 \%$ or less of their income for food. While $35.9 \%$ of the household allocated $40 \%$ or less for food, $35.1 \%$ allocated 41 to $60 \%$ of their income and $29.0 \%$ allocated $61 \%$ and more of their income. Similarly, Gümüş et al. (2010) examined food expenses of 386 households from 48 villages of 12 counties in the Aegean Region in 2007. They determined that the average percentage the household allocate for food expenses was $42.29 \%$. These two data sets indicate the income inequality in the rural areas.

\section{Results}

\subsection{Examination of the HFIAS Conditions of the Sample}

Average HFIAS score is a sensitive indicator of household food insecurity. However, those who carry out social relief programs, beneficiaries and politicians always want to know the rate of household food insecurity and to what extend this situation has changed after the relief programs. This makes classifications, which precisely indicate the severity of hunger, necessary. Therefore, in this study based on the previous studies (e.g. Swindale and Bilinsky, 2006; Coates et al., 2007; Melgar-Quinonez et al., 2006), food insecurity was classified into four categories. The first two questions were related with "slight (without hunger) food insecurity"; the third, fourth and fifth questions were related with "food insecurity with moderate hunger"; the sixth, seventh, eighth and ninth questions were related with "food insecurity with severe hunger". Those who did not give positive answer to any questions were accepted to have "food security" (Table 5).

In order to determine how many people or households there were in each category, first, the number of those who positively answered any one of the questions related to severe hunger (6, $7,8,9)$ was determined (245 people). Next answer these questions positively (100 people) but answered any one of the questions related with partial hunger $(3,4,5)$ positively $(48$ people) was determined. Among the remaining 42 people, the number of those who positively answered one of the questions related with slight food insecurity $(1,2)$ was determined $(15$ people). The 27 people who did not answer any questions positively represented the households who had food security (Table 5).

As is seen in Table 5, 71\% of the household in the sample group accepted "food insecurity with sever hunger", $16.8 \%$ accepted "food insecurity with partial hunger" and $12.2 \%$ accepted "slight (without hunger) food insecurity. Severe food insecurity was mostly experienced as eating less than necessary $(52.5 \%)$ and starving (43.5\%). Yet, losing weight 
$(27.5 \%)$ or spending the whole day hungry $(20.6 \%)$ due to severe food insecurity was not seen.

Table 5. HFIAS levels of the sample group $(n=345)$

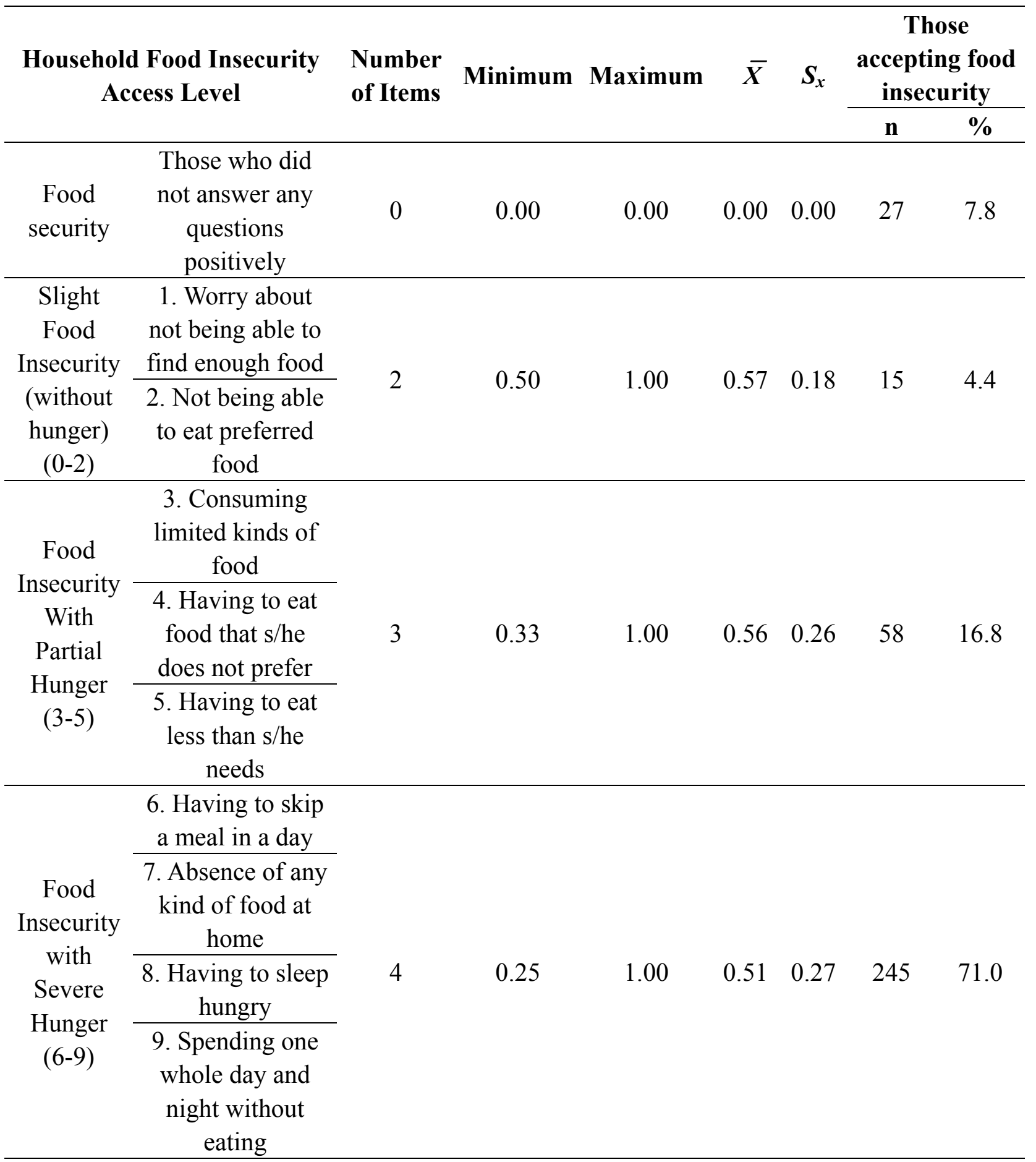

Besides, as seen in Table 6 we investigated how often sample group experience food 
insecurity. Although most of the sample group (71\%) accepted "food insecurity with severe hunger, it was found that participants accepted food insecurity without hunger more frequently ( $\bar{X}=1.31$ ) and that they accepted food insecurity with partial hunger $(\bar{X}=0.92)$ and severe hunger ( $\bar{X}=0.65$ ) less frequently (Table 6 ). This result can be accepted as an indicator of the fact that the sample group's diets do not have adequate variety for them to eat balanced and healthy diet.

Table 6. HFIAS frequencies of the sample group $(n=318)$

\begin{tabular}{|c|c|c|c|c|c|c|c|c|c|}
\hline \multirow[t]{2}{*}{ Frequen } & \multirow[t]{2}{*}{$\begin{array}{l}\text { cy of Household Food } \\
\text { Insecurity }\end{array}$} & \multicolumn{2}{|c|}{$\begin{array}{l}\text { Rarely } \\
\text { (once or } \\
\text { twice in } \\
\text { the last } \\
\text { four } \\
\text { weeks) }\end{array}$} & \multicolumn{2}{|c|}{$\begin{array}{l}\text { Sometimes } \\
\text { ( three to } \\
\text { ten times } \\
\text { for the last } \\
\text { four } \\
\text { weeks) }\end{array}$} & \multicolumn{2}{|c|}{$\begin{array}{c}\text { Frequently } \\
\text { ( more than } \\
\text { ten times in } \\
\text { the last } \\
\text { four } \\
\text { weeks) }\end{array}$} & \multirow[t]{2}{*}{$\begin{array}{c}\bar{X} \\
\\
\mathrm{n}\end{array}$} & \multirow{2}{*}{$\begin{array}{l}S_{x} \\
\\
\% \\
\end{array}$} \\
\hline & & $\mathrm{n}$ & $\%$ & $\mathrm{n}$ & $\%$ & $\mathrm{n}$ & $\%$ & & \\
\hline \multirow{2}{*}{$\begin{array}{l}\text { Slight } \\
\text { Food } \\
\text { Insecurity } \\
\text { (without } \\
\text { hunger) } \\
(0-2) \\
\end{array}$} & $\begin{array}{l}\text { 1. Worry about not being } \\
\text { able to find enough food }\end{array}$ & 112 & 35.2 & 78 & 24.5 & 48 & 15.1 & \multirow[b]{2}{*}{1.31} & \multirow[b]{2}{*}{0.87} \\
\hline & $\begin{array}{l}\text { 2. Not being able to eat } \\
\text { preferred food }\end{array}$ & 79 & 24.8 & 106 & 33.3 & 43 & 13.5 & & \\
\hline \multirow{3}{*}{$\begin{array}{c}\text { Food } \\
\text { Insecurity } \\
\text { With } \\
\text { Partial } \\
\text { Hunger } \\
(3-5)\end{array}$} & $\begin{array}{l}\text { 3. Consuming limited } \\
\text { kinds of food }\end{array}$ & 98 & 30.8 & 86 & 27.0 & 31 & 9.7 & \multirow{3}{*}{0.92} & \multirow{3}{*}{0.78} \\
\hline & $\begin{array}{l}\text { 4. Having to eat food that } \\
\text { s/he does not prefer }\end{array}$ & 76 & 23.9 & 87 & 27.4 & 47 & 14.8 & & \\
\hline & $\begin{array}{l}\text { 5. Having to eat less than } \\
\text { one needs }\end{array}$ & 88 & 27.7 & 58 & 18.2 & 38 & 11.9 & & \\
\hline \multirow{4}{*}{$\begin{array}{c}\text { Food } \\
\text { Insecurity } \\
\text { with } \\
\text { Severe } \\
\text { Hunger } \\
(6-9)\end{array}$} & $\begin{array}{l}\text { 6. Having to skip a meal } \\
\text { in a day }\end{array}$ & 91 & 28.6 & 59 & 18.6 & 31 & 9.7 & \multirow{4}{*}{0.65} & \multirow{4}{*}{0.63} \\
\hline & $\begin{array}{l}\text { 7. Absence of any kind of } \\
\text { food at home }\end{array}$ & 75 & 23.6 & 44 & 13.8 & 31 & 9.7 & & \\
\hline & $\begin{array}{l}\text { 8. Having to sleep } \\
\text { hungry }\end{array}$ & 52 & 16.4 & 28 & 8.8 & 15 & 4.7 & & \\
\hline & $\begin{array}{l}\text { 9. Spending one whole } \\
\text { day and night without } \\
\text { eating }\end{array}$ & 36 & 11.3 & 27 & 8.5 & 8 & 2.5 & & \\
\hline
\end{tabular}

3.2 Examination of the Relation between HFIAS Conditions of the Sample Group and the Independent Variables

The relation between HFIAS conditions of the sample and the independent variables are 
given in Table 7. In Table 7, each three type of food insecurity were found to be significantly related $(p<0.001)$. The reason of this is that those who suffer from food insecurity with severe hunger also answered questions about food insecurity with partial hunger and without hunger positively and similarly those who suffer from food insecurity with partial hunger answered some questions in other categories positively.

Table 7. Pearson correlation coefficient of the HFIAS levels of the samples in terms of demographic variables $(n=318)$

\begin{tabular}{|c|c|c|c|c|c|c|c|c|}
\hline & $\begin{array}{c}\text { Slight } \\
\text { Food } \\
\text { Insecurity }\end{array}$ & $\begin{array}{c}\text { Food } \\
\text { Insecurity } \\
\text { with } \\
\text { Partial } \\
\text { Hunger } \\
\end{array}$ & $\begin{array}{c}\text { Food } \\
\text { Insecurity } \\
\text { With } \\
\text { Severe } \\
\text { Hunger } \\
\end{array}$ & Gender & $\begin{array}{c}\text { Age } \\
\text { Groups }\end{array}$ & $\begin{array}{l}\text { Income } \\
\text { Groups }\end{array}$ & $\begin{array}{l}\text { Monthly } \\
\text { Food } \\
\text { expenses }\end{array}$ & $\begin{array}{l}\text { Number } \\
\text { of } \\
\text { Household } \\
\text { members }\end{array}$ \\
\hline $\begin{array}{c}\text { Slight } \\
\text { Food } \\
\text { Insecurity } \\
\text { (Without } \\
\text { Hunger) }\end{array}$ & & $0.337 * * *$ & $0.213 * * *$ & $-0.270 * * *$ & -0.077 & $-0.207 * * *$ & -0.039 & 0.032 \\
\hline $\begin{array}{c}\text { Food } \\
\text { Insecurity } \\
\text { With } \\
\text { Partial } \\
\text { Hunger }\end{array}$ & & & $0.376 * * *$ & $-0.186 * *$ & -0.082 & $-0.194 * * *$ & $-0.112 *$ & -0.008 \\
\hline $\begin{array}{c}\text { Food } \\
\text { Insecurity } \\
\text { With } \\
\text { Severe } \\
\text { Hunger }\end{array}$ & & & & -0.081 & 0.015 & $-0.198 * * *$ & -0.087 & $0.117 *$ \\
\hline
\end{tabular}

As shown in Table 7 the relation with food insecurity level and gender is examined, it was determined that compared to men, women accepted food insecurity with slight hunger $(\mathrm{r}=$ $-0.270 ; p<0.001)$ and with partial hunger $(r=-0.186 ; p<0.01)$ more. On the other hand, no significant relation between individuals' food insecurity acceptance levels and age groups was found $(\mathrm{p}>0.05)$. Besides, all three food insecurity levels are related to income groups $(\mathrm{p}<0.001)$. In other words, as income level and families' monthly food expense decreased, the rate of individuals experiencing food insecurity increased. Similarly, as monthly food expenses decreased, food insecurity with partial hunger decreased $(r=-0.112 ; p<0.01)$. Also the relation between the number of people in the family and the level of participants' experience food insecurity with sever hunger increased $(r=0.117 ; \mathrm{p}<0.05)$ is found (Table 7). 


\section{Discussion}

\subsection{Discussion About Results}

In our study $71 \%$ of the household in the sample group accepted "food insecurity with sever hunger" and severe food insecurity was mostly experienced as eating less than necessary (52.5\%) (Table 5). Similarly, in a study by Frongillo and Nanama (2006), in which they examined seasonal change in food insecurity experienced in the northern rural areas of Burkina Faso, it was revealed that there was a relation between eating less frequently and higher food insecurity.

Besides, as seen in Table 6 we found how often the sample group experiene food insecurity. Although most of the sample group (71\%) accepted "food insecurity with severe hunger, it was found that participants accepted food insecurity without hunger more frequently ( $\bar{X}=$ 1.31). As a matter of fact, in a study by Kocakayta (2007) on the budget minimum wage workers allocated for food and their food consumption frequency, it was found that while $88.1 \%$ of the participants stated that there was not any food they could not buy due to financial difficulties, $9.0 \%$ pointed out that they could not afford red meat and similar items. Following from these data, it can be argued that even minimum wage household consumed limited variety of food and experienced slight food insecurity. As we have already mentioned, the amount of minimum wage is lower than poverty and hunger threshold. Thus, in this case it is highly possible that the food consumed will not be of adequate variety. According to the statistic analyses conducted all over the country, it was seen that while there was increase in household income, there was a significant decrease in red meat consumption. While the red meat consumption per capita was $20.7 \mathrm{~kg}$ in 1994, with a decrease by $51.2 \%$ this figure dropped down to $10.1 \mathrm{~kg}$ in 2005 . However, red meat consumption for the same year was 72 $\mathrm{kg}$ in the US and $60 \mathrm{~kg}$ in the European Union (EU), which was six to seven times more than in Turkey. This results from high consumer prices due to low productiveness, high feed prices, high tariffs and import restrictions in the country. Therefore, chicken $(214 \%)$, pasta $(53.8 \%)$ and rice $(21.3 \%)$ consumption of Turkish population who had difficulty in buying red meat and meat products increased substantially in the same period (1994-2005) (TZOB, 2008). In other words, $44 \%$ of daily energy intake in Turkey came from bread only and $58 \%$ from bread and other cereal products (Eraktan \& Yelen, 2012). The figures belonging to years between 2005 and 2007 indicated that people obtained 62\% of their energy intake from carbohydrates, $11 \%$ from proteins and 12\% from animal products (Ataseven et al., 2012). In this case, it can be argued that a significant part of daily diet of Turkish people is based on cereals and that the poor cannot take animal protein and thus may experience deficiency of some essential nutritional elements.

We also examined the data sets from other studies on this issue in chronological order. In their study Hamilton et al. (1997) and Carlson et al. (1999), which they conducted to determine food insecurity and hunger level in the US, estimated that $11.9 \%$ (35 million) of the household experienced food insecurity. When they graded food insecurity, they found that $7.8 \%$ (7.78 million people) felt slight food insecurity, in other words they did not suffer from hunger; $3.3 \%$ (3.34 million people) experienced food insecurity with partial hunger; $0.8 \%$ 
(817 thousand people) suffered from food insecurity with severe hunger. Similarly, in a study by Gutherie and Nord (2002), according to findings of the survey conducted by the United States Department of Agriculture (USDA) in July 2000, it was revealed that $89.5 \%$ of the United States (US) household has food security throughout the year. It was determined that sometimes in almost 3.1\% (3.3 million household) of the group without food insecurity, which accounts for the $10.5 \%$ of the population, one or more than one household members experienced food insecurity to an extend to hunger due to shortage of supply at least a few times a year. In a study by Coleman-Jensen et al. (2011) in which they investigated the recent developments about food insecurity in the US in 2010, it was determined that almost $14.5 \%$ (almost 17.2 million) of the total population experienced food insecurity, and that $9.1 \%$ of the people suffered from severe food insecurity and 5.4\% (which corresponds to 6.4 million) suffered from very severe food insecurity; in other words, they were starving. When the former two studies are compared with the latter, it was seen that although the percentages in the last study seemed to be higher, when the population rates were considered, the rate of food insecurity in the US decreased over the last decade. However, the high number of the population with food insecurity in the US, which is one of the few developed countries in the world, is striking. This rate indicates that food insecurity is not only a phenomenon in underdeveloped countries but also in developing and even in developed countries.

Labadarios and Nel (2000) studied food insecurity level of 2613 children aged between 1 and 9 according to "South African National Food Consumption Survey" in 1999. To measure hunger level, questions about whether household had enough money to buy food and adequate food, whether they consumed adequate amount of food and/or whether children were ever hungry were asked. Answering five questions out of eight positively was accepted as the indicator of food insecurity and these households were accepted as "hungry". Results indicated, 60 to $73 \%$ of the household of the sample group experienced food insecurity and in $30 \%$ of the sample children experienced hunger. All families in general protect their children from experiencing food insecurity and therefore inadequate food intake and hunger experienced by children indicate the famililies' inability to access food to have reached at its end point. Similarly, among adults, decrease in food intake was larger and for a longer period of time. Therefore, these results indicated that food insecurity was experienced very intensively.

In their food insecurity study on 600 individuals in the countryside in Bangladesh between 2001 and 2003, Coates et al. (2006a) found that 90\% of household experienced food insecurity. It was determined that $3.3 \%$ of the study group experienced slight food insecurity; $43.2 \%$ experienced food insecurity with partial hunger, $20 \%$ experienced high level of food insecurity and 33.\% experienced food insecurity with severe hunger. This case indicates that serious food insecurity at malnutrition level was experienced in Bangladesh.

In their study in which they examined food insecurity in Bolivia in the South America, in Burkina Faso in the West Africa and in the Philippines in the Southeastern Asia, Melgar-Quinonez et al. (2006) used 9-item United States Household Food Security Survey Module (US HFSSM). Besides, they compared their findings with daily food consumption amounts. It was determined that food insecurity with severe hunger was experienced most in 
Burkina Faso (51.2\%) and then in Bolivia (43.4\%) and at least in the Philippines (14.0\%). Food insecurity with partial hunger were at similar levels (Bolivia: 26.9\%; Burkina Faso: 21.8\%; Philippines: 21.5\%) and slight food insecurity rate was higher in the Philippines (64.5\%) compared to the other two countries (Bolivia: 29.7\%; Burkina Faso: 27.0\%). Therefore, it was concluded that food insecurity among these three countries compared was slighter in the Philippines and severer in Burkina Faso and Bolivia.

Coates et al. (2006b) attempted to determine intercultural similarities in food insecurity experiences in 15 different countries and used a 22-item scale. The questions were later reduced to 11 items considering household answers and cultural differences. As a result of analysis, it was determined that the amount and quality of food in the sampled cultures was inadequate, food availability was uncertain and that they had worries about being socially isolated due to food insecurity. Besides, it was determined that they were overanxious about food security and upset in their eating habits. Among the countries where severe food insecurity was examined, especially in Bolivia, Burkina Faso, Ghana and the Philippines, food insecurity was mostly reported as experience of hunger. In other 11 countries, food insecurity was more frequently reported as eating less than one meal a day or skipping meals.

The study by Chambers (2007) in which the relation between food purchasing adequacy and food security of 67 households was examined in Las Cruces, New Mexico, is based on the fact that the fundamental characteristic of a healthy diet is diversity. Thus, households with low food insecurity, food items in the diet had limited diversity. This finding can be accepted as an indicator of food insecurity without hunger. By the same token, Labadarios et al. (2011) studied the diet diversity of 3287 people over 16 in South Africa. In their study, 4 or fewer type of food from 9 food types was accepted to be poor diet diversity reflected poor food security. It was determined that among participants in tribal areas $(63.9 \%)$ and informal urban areas $(55.7 \%)$, were very much affected by food insecurity.

As a result, it can be said that food insecurity in Turkey is not as frequent and chronic as it is Bangladesh, Bolivia, Burkina Faso, the Philippines and South African countries but it involves non-negligible amount of population as in Mexico and the US.

In this study we also examined the relation between food insecurity level and demographic variables. As a result of statistical analysis it was determined that compared to men, women accepted food insecurity with slight hunger $(p<0.001)$ and with partial hunger $(p<0.01)$ more (Table 7). This can be attributed to the traditional family structure in the Eastern Anatolia, where women are more responsible for the kitchen and thus can better percept the needs in the kitchen. Another reason can be that women restrict their diets. As a matter of fact, in a study by Rose (1999) it was determined that most of the household who suffer from poverty and hunger in the US of the 1995 were adult women and elderly adults (50\%). It was observed that the pre-school aged members of households who suffer from food insecurity did not consume as low amount of food as the other members of the household. This result indicates that adults in absolute poverty and especially women decrease their diets so as to feed their young ones adequately. In a study by Mukherjee (2010) it was argued that due to traditional reasons women and girls in South Africa were exposed to food insecurity more 
than other members of the household.

On the other hand, no significant relation between individuals' food insecurity acceptance levels and age groups was found ( $>0.05$ ) (Table 7$)$. The reason for this can be that all the individuals in the household were adults. If food insecurity questionnaire had been applied to children, perhaps we would have found a significant difference between age groups as in Rose's (1999) study.

Naturaly in this study we found that as income level and families' monthly food expense decreased, the rate of individuals experiencing food insecurity increased $(p<0.001)$ (Tablo 7). Besides we found that a relation between the number of people in the family and the level of participants experience food insecurity with sever hunger increased $(p<0.05)$ (Table 7). Because it is plausible that food insecurity was experienced more severely as the number of household increased and thus the number of income-earning individuals increased relatively and/or the number of the dependent individuals increased. When the condition all over Turkey is examined based on 2009 TÜIKK data, it can be seen that while the poverty rate in nuclear family was $12.98 \%$, this rate increase to $21.43 \%$ in patriarchal or large families (TÜİK, 2009a). Similarly, in a study by Sahn and Stifel (2000) in which they compared intercultural poverty in the US between 1980 and 1992, they revealed that food expense increased as the household increased but the amount spent per capita decreased. It was even reported that one person household (42\%) spent twice as much money on food compared to household with six and more members (20\%). In a study by Sharafkhani et al. (2010) in the North of Iran, it was found that although household food insecurity was not found to be related with the number of children (under age 5) and elderly at home, it was found to be related with family size.

\subsection{Discussion About Measurements}

Various data collection tools are used in food insecurity measurements. Most household food security measurements are the sum of the direct and indirect indicators which inquiry food consumption and reflect food provision and access. The food access indicators are also socio-economic indicators and reveal the power of household to overcome various stresses stemming from economic and social changes. Food access measurements are useful in assessing food deficit differences and household food insecurity type (e.g. seasonal or constant), in observing changes in conditions and in assessing household susceptibility to various social and economic shocks and the damages caused as they resist these shocks. Direct indicator measures food insecurity experiences (for instance food consumption measurements, household's perception of food insecurity or hunger and food consumption frequencies). Direct indicators are the best measurements as they provide more profound data as more time spent observing and interviewing household members. As for indirect household food insecurity measurements, it is difficult to reach information and data collection is costly. Indirect indicators include daily food intake differences, storage calculations in critical times of the year, sustention potentials of households mostly dependent on agriculture (the rate of daily energy intake from food to the food accessed) and nutritional assessments (antropometric indicators) (Hendriks, 2005). 
In fact food insecurity and hunger are related terms but not equivalent terms. Here food security and insecurity were discussed as always having the financial ability to purchase socially acceptable and nutritional food. Hunger is defined as repeated and involuntary decrease in food intake and spoilage of regular eating order. In this respect, it can be regarded as a severe phase or level of food insecurity (Gutherie \& Nord, 2002). Therefore, the questions on the HFIAS, which is used to gain better insight into household food insecurity conditions, reflect the worsening food insecurity phases in various households. In the first phase, household suffer from inadequacies in food provision and from shortage in their food budget and thus, worry about not being able to meet their basic food substances and try to adjust the types of food according to their budget allocated for food. In the second phase, a significant decrease is seen in the type of food and their diets do not include most of the essential food groups. When the situation gets more serious, the food intake of the household decreases and they experience hunger. The categorical measurement of food insecurity is divided on a scale with intervals. This procedure classifies the household in one of the four categories: food insecurity, food insecurity without hunger, food insecurity with partial hunger and food insecurity with severe hunger.

\subsection{The Limitations of the Study and Suggestions for Further Studies}

The severity of food insecurity varies from one country to another and a different scale is to be developed for each country. As a matter of fact, Blumberg et al. (1999) studied the effectiveness of 18-item US HFIAS which was developed to measure severity of hunger. It was estimated with this scale that $11.9 \%$ of the US population ( 35 million) experienced food insecurity. Then, it was determined that $65.9 \%$ of this group did not suffer from hunger; $28.0 \%$ experienced partial hunger (3.3\% of the US population); $6.9 \%$ suffered from severe hunger ( $0.8 \%$ of the US population) with food insecurity. In line with these data, Blumberg et al, concluded that this scale was not appropriate to measure food insecurity because it was seen that a very small per cent of the population $(0.8 \%)$ suffered from food insecurity with hunger. With an aim to reveal the real situation of the people, the 18 -item form was reduced to 6 items and the questions related with food insecurity without hunger and food insecurity with partial hunger were used. Thus, it was determined that the scale $97.7 \%$ correctly measured food insecurity level of all population from different socio-economic levels and included only $3.3 \%$ margin of error.

In our study, it can be argued that $71 \%$ of the sample group suffered from severe food insecurity (rarely tough) and when it is considered that those who live with less than $\$ 1.25 \mathrm{a}$ day, make up $2.6 \%$ of the country's population, it can be said that the scale is adequate enough to be applied to the whole country. However, the scale applied to the adults might not have reflected their real situations as they were distributed to the adults via their children. Therefore, in our next study, we are considering to apply the scale to all individuals in the family and ask children to assess their food insecurity separately. It is assumed that more clear results about food insecurity in Turkey can be obtained by using these data.

\section{References}

Açlık ve Yoksulluk Sınırı. (2010). Ekim 2010 Açlık ve Yoksulluk Sınırı. TÜRK-İŞ (Türkiye 
İşçi Sendikaları Konfederasyonu) Haber Bülteni, 275. Bülten, 28 Ekim 2010.

Arpacıŏlu, Özge \& Metin Yıldırım. (2011). Dünyada ve Türkiye'de Yoksulluğun Analizi. Niğde Üniversitesi İ̈BF Dergisi, 4(2), 60-76.

Ataseven, Yener, Hasan Arısoy \& Özdal Köksal. (2012). Türkiye'de Tarım Politikalarının G1da Güvencesi ve Güvenliği Açısından Değerlendirilmesi. 10. Ulusal Tarım Ekonomileri Kongresi Bildiriler Kitabı, 5-7 Eylül 2012, Konya: Cilt 1,174-181.

Avşar Kurnaz, Şebnem. (2007). Çocuk Yoksulluğu. Aile ve Toplum, 3(12), Nisan-MayisHaziran, 47-55.

Baysal, Ayşe. (2003). Sosyal Eşitsizliklerin Beslenmeye Etkisi. C. Ü. Tıp Fakültesi Dergisi, 25(4), 66-72.

Blumberg, Stephen J., Karil Bialostosky, William L. Hamilton \& Ronette R. Briefel. (1999). The Effectiveness of a Short Form of the Household Food Security Scale. American Journal of Public Health, 89(8), 1231-1234. http://dx.doi.org/10.2105/AJPH.89.8.1231

Caldwell, W., A. Collett, T. Ludlow, I. Sinclair \& Whitehead, J. (2011). Planning and Food Security within the Commonwealth: Discussion Paper 2/ February, 2011, Commonwealth $\begin{array}{lllll}\text { Foundation. } & \text { Retrieved } & \text { May } & \text { 2012, from }\end{array}$ http://www.commonwealth-planners.org/papers/food.pdf

Carlson, Steven J., Margaret S. Andrews \& Gary W. Bickel. (1999). Measuring Food Insecurity and Hunger in the United States: Development of a National Benchmark Measure and Prevalence Estimates. American Society for Nutrition, 129(2), 510-516.

Coates, Jennifer, Anne Swindale \& Paula Bilinsky. (2007). Household Food Insecurity Access Scale (HFIAS) for Measurement of Food Access: Indicator Guide. Food and Nutrition Technical Assistance Project (FANTA), Academy for Educational Development, Washington, DC, Website: www.fantaproject.org.

Chambers, Rebecca L. (2007). An Exploratory Study of Local Food Affordability and Factors Related to Household Food Security and Food Purchasing Decisions. The Internet Journal of Health, 5(2), 1-14.

Chenoweth, Florence. (2007). Reducing Hunger in Sub-Saharan Africa: A Sound Investment to Boost Economic Growth and Alleviate Poverty. Turkish Asian Center for Strategic Studies (TASAM: Türk Asya Stratejik Araştırmalar Merkezi) (01.09.2007) Retrieved January 2, 2013, http://www.tasam.org/en/Icerik/3955/reducing_hunger_in_sub-saharan_africa_a_sound_inves tment_to_boost_economic_growth_and_alleviate_poverty

Coates, Jennifer, Parke E. Wilde, Patrick Webb, Beatrice Lorge Rogers \& Robert F. Houser. (2006a). Comparison of a Qualitative and a Quantitative Approach to Developing a Household Food Insecurity Scale for Bangladesh. American Society for Nutrition, 136(5), $1420-1430$.

Coates, Jennifer, Edward A. Frongillo, Beatrice Lorge Rogers, Patrick Webb, Parke E. Wilde, 
\& Robert Houser. (2006b). Commonalities in the Experience of Household Food Insecurity across Cultures: What Are Measures Missing? American Society for Nutrition, 136(5), $1438-1448$.

Coleman-Jensen, Alisha, Mark Nord, Margaret Andrews \& Steven Carlson. (2011). Household Food Security in the United States in 2010. United States Department of Agriculture (USDA), Economic Research Service, 1-29.

Çabuk Kaya, Nilay. (2006). Güneydoğu Anadolu Bölgesindeki Hanelerin Sosyo-Ekonomik Düzeylerine Göre Beslenmedeki Tüketim Kalıpları. I. Uluslar Arası Ev Ekonomisi Kongresi Bildiriler Kitabı, 22-24 Mart, Ankara: Oluşum Yayınc1lık: 260-275.

Demir Şeker, Sırma \& Müşerref Küçükbayrak. (2012). Türkye’de Bölgesel Asgari Ücretin Uygulanabilirliği. (31.07.2012).

Dowler, Elizabeth. (2003). Food and Poverty: Insights form the 'North'. Development PolicyReview, 21(5-6), 569-580. http://dx.doi.org/10.1111/j.1467-8659.2003.00224.x

DPT (Devlet Planlama Teşkilatı). (2001). Gelir Dağılımının İyileştirilmesi ve Yoksullukla Mücadele Özel İhtisas Komisyon Raporu. 9. Beş Yıllık Kalkınma Planı, DPT Yayınları, (Yayın No: DPT: 2599- ÖİK: 610), Ankara. Accessed on 31 August 2012 from http://www.dpt.gov.tr/DocObjects/Download/3089/oik610.pdf

Dünya Çocuk Günü’nde Yenibinyıl'ın Dünya Çocukları Sayısal Çocuk Uyarı Raporu. (2011). $\begin{array}{llll}\text { Retrieved August } & \text { 3, } & \text { from }\end{array}$ http://www.cocukvakfi.org.tr/resource/pdf/Raporlar/4yenibinyilin_dunya_cocuklari_raporu.pdf

Ensari, Sıddık. (2010). TÜİK'in Yoksulluk Analizleri Üzerine. Güncel, 24(87), 9-15.

Eraktan, Selahattin, Neslihan Köse \& İlkay Kutlar. (2006). Gelir Farklılıklarının Gıda Maddeleri Tüketim Miktarına ve Niteliklerine Etkisi. I. Uluslar Arası Ev Ekonomisi Kongresi, 22-24 Mart, Ankara: Oluşum Yayıncılık, 516-522.

Eraktan, Gülcan \& Berna Yelen. (2012). Üretici, Tüketici ve Yoksulluk Olgusu Yönünden Türkiye'de Gida Güvencesi. 10. Ulusal Tarım Ekonomileri Kongresi Bildiriler Kitabı, 5-7 Eylül 2012, Konya: Cilt 1: 121-128.

Finke, Michael, Luther Tweeten \& Wen Chern. (1996). Economic Impact of Proper Diets on Farm and Marketing Resources. Agribusiness (1986-1998), 12 (3), May/ June: 201-207.

Food and Agriculture Organization of United Nations (FAO). (2003). Trade Reforms and Food Security: Conceptualizing The Linkages. Commodity Policy and Projections Service, Rome.

Frongillo, Edward A. \& Siméon Nanama. (2006). Development and Validation of an Experience-Based Measure of Household Food Insecurity within and across Seasons in Northern Burkina Faso. American Society for Nutrition, 136(5), 1409-1419.

Gutherie, Joanne F. \& Nord, Mark. (2002). Federal Activities to Monitor Food Security. Journal of the American Dietetic Association, 102(7), 904-906. 
http://dx.doi.org/10.1016/S0002-8223(02)90202-6

Gümüş, Sevtap Güler, Fazıl Akın Olgun \& Hakan Adanacıoğlu. (2010). Food Consumption Patterns in Rural Turkey and Poverty. African Journal of Agricultural Research, 5(1), 16-27.

Günindi Ersöz, Aysel. (2003). Dünya Konferansları Belgelerinde Aile ve Yoksulluk: Saptamalar ve öneriler. Aile ve Toplum Dergisi, 2(6), 71-80.

Hamilton, William L., John T. Cook, William W. Thompsona, Lawrence F. Burona, Edward A. Frongillo, Christine M. Olsonc \& Cheryl A. Wehlerd. (1997). Household Food Security in the United States in 1995: Summary Report of the Food Security Measurement Project. Alexandria, Va: US Dept of Agriculture, Food and Consumer Service; September 1997.

Haseen, Farhana \& Munshi Sulaiman. (2007). How Sustainable is the Gain in Food Consumption of the CFPR/TUP Beneficiaries? CFPR Working Paper Series No. 18, Published by BRAC-AKFC Learning Partnership Project for CFPR with funding support from the Canadian International Development Agency (CIDA).

Hendriks, Sheryl L. (2005). The Challenges Facing Empirical Estimation of Household Food (in) Security in South Africa. Development Southern Africa, 22(1), 103-123. http://dx.doi.org/10.1080/03768350500044651

Jensen, Helen H. \& Justo Manrique. (1998). Demand for Food Commodities by Income Groups in Indonesia. Applied Economics, 30, 491-501. http://dx.doi.org/10.1080/000368498325750

Kalınkara, Velittin. (2011). Temel Gerontoloji Yaşlılık Bilimi. Denizli: Nobel Yayını.

Kalyoncu, Kahraman. (2009). Gıda Harcamalarının Gelir İçindeki Payı Yönünden Satın Alma Gücünün Değerlendirilmesi: Türkiye'nin Bölgeselleştirilmiş İlleri Bazında Bir Değerlendirme. Niğde Üniversitesi İ̈BF Dergisi, 2(1), 18-26.

Kızılaslan, Nuray, Halil Kızılaslan, Hasan Gökhan Doğan \& Derya Ağcadağ. (2012). Türkiye'nin İnsani Yoksulluk Boyutu. 10. Ulusal Tarım Ekonomileri Kongresi Bildiriler Kitabı, 5-7 Eylül 2012, Konya: Cilt 1, 450-456.

Kocakayta, Ali Haydar. (2007). Asgari Ücretli Ailelerin Gıdaya Ayırdıkları Bütçenin ve Gıdaları Tüketim Sıklıklarının Belirlenmesi. Gazi Üniversitesi Eğitim Bilimleri Enstitüsü Aile Ekonomisi ve Beslenme Anabilim Dalı Yüksek Lisans Tezi, Ankara.

Koç, Beşir \& Aykut Gül. (2006). Türkiye'de Kırsal Kalkınma Modeli Olarak Köykentlerde Kırsal Toplumun Yaşam Kalitesi. I. Uluslar Arası Ev Ekonomisi Kongresi, 22-24. Mart, Ankara: Oluşum Yayıncılık: 126-135.

Labadarios, Demetre \& Johanna Nel. (2000). Anthropometric status. In Labadarois D (Ed.), The National Food Consumption Survey (NFCS): Children Aged -9 years, South Africa, 1999 (online document). Accessed at 29 December 2012 from http://www.sahealthinfo.org/nutrition/food4anthrostatus.pdf

Labadarios, Demetre, Nelia Patricia Steyn \& Johanna Nel. (2011). How Diverse is the Diet of 
Adult South Africans? Nutrition Journal, 10, 33. http://dx.doi.org/10.1186/1475-2891-10-33

Melgar-Quinonez, Hugo R., Ana C. Zubieta, Barbara MkNelly, Anastase Nteziyaremye, Maria Filipinas D. Gerardo \& Christopher Dunford. (2006). Household Food Insecurity and Food Expenditure in Bolivia, Burkina Faso, and the Philippines. American Society for Nutrition, 136(5), 1431-1437.

MuhasebeBlog. (2014). 2000-2014 Y1lı Asgari Ücretleri ve Dolar Kurları.

Mukherjee, Amitava. (2010). Food Insecurities Faced by Women and Girl Children. CAPSA-ESCAP Occasional Paper, June: 1-19.

Oğuz, Cennet, Hüseyin Ergun, Mustafa Kan, Murat Küçükcongar, Arzu Kan \& Emel Demiröz. (2012). Poverty in Agricultural and Rural Community; A Case Study from Konya, Turkey. $1^{\text {st }}$ International Interdisciplinary Social Inquiry Conference, 17-21. June 2012, Bursa: Uludağ University.

Oğuz, Cennet, Hüseyin Ergun, Murat Küçükcongar, Mustafa Kan, Arzu Kan \& Emel Demiröz. (2012). Konya İli Tarım Havzalarında Tarım İşletmelerinin Sosyo-Ekonomik Yapısı, Arazi ve Gelir Dağılımı. 10. Ulusal Tarım Ekonomileri Kongresi Bildiriler Kitabı, 5-7 Eylül 2012, Konya: Selçuk Üniversitesi: 657-666.

Öztürk, Mustafa \& Başak Işıl Çetin. (2009). Dünyada ve Türkiye'de Yoksulluk ve Kadınlar. Journal of Yasar University, 3(11), 2661-2698.

Rose, Donald. (1999). Economic Determinants and Dietary Consequences of Food Insecurity in the United States. American Society for Nutritional Sciences, 129(2), 517-520.

Sallan-Gül, Songül. (2002). "Türkiye'de Yoksulluk ve Yoksullukla Mücadelenin Sosyolojik Boyutları: Göreliden Mutlak Yoksulluğa”, Yoksulluk, Şiddet ve Insan Hakları. (Editör: Yasemin Özdek), 1. Baskı, Ankara: TODAİE Yayını.

Saner, Gamze, Figen Çukur \& Simge Saner. (2012). Küreselleşme, Yoksulluk ve Tarım. 10. Ulusal Tarım Ekonomileri Kongresi Bildiriler Kitabı, 5-7 Eylül 2012, Konya: Cilt 1: 493-498.

Sahn, David E. \& David C. Stifel. (2000). Poverty Comparisons Over Time and Across Countries in Africa. World Development, 28(12), 2123-2155. http://dx.doi.org/10.1016/S0305-750X(00)00075-9

Sharafkhani, Rahim, Saeed Dastgiri, Rasool Gharaaghaji, Saeed Ghavamzadeh \& Alireza Didarloo. (2010). The Role of Household Structure on The Prevalence of Food Insecurity. European Journal of General Medicine, 7(4), 385-388.

Swindale, Anne \& Paula Bilinsky. (2006). Development of a Universally Applicable Household Food Insecurity Measurement Tool: Process, Current Status, and Outstanding Issues. American Society for Nutrition, 136(5), 1449-1452.

TZOB (Türkiye Ziraat Odaları Birliği). (2008). Türkiye Kırmızı Et Sektör Değerlendirmesi 2008 Yılı ve Sonrası Beklentiler. Ankara: Türkiye Ziraat Odaları Birliği Yayını. 


\section{Macrothink}

Journal of Social Science Studies

ISSN 2329-9150

2015, Vol. 2, No. 1

Türkiye İstatistik Kurumu (TÜIK). (2008). TÜIKK Yoksulluk Çalışmaları. T.C. Başbakanlık Türkiye İstatistik Kurumu Yayını (20.12.2008). Accessed on 29 August 2012 from http://eaf.ku.edu.tr/sites/eaf.ku.edu.tr/files/20122008-3.pdf

Türkiye İstatistik Kurumu (TÜİK). (2010). 1923-2010 İstatistiki Göstergeler, Türkiye İstatistik Kurumu Yayını $\quad$ Retrieved December 3, 2012, from http://www.ecosn.org/Portals/0/Publications/Turkey/Turkey-Statistical-Indicators-2010.pdf

Türkiye İstatistik Kurumu (TÜİK). (2012a). Yoksulluk Çalışması, 2011. T.C. Türkiye İstatistik Kurumu Haber Bülteni (8642) (16.03.2012). Accessed on 29 August 2012 from http://www.tuik.gov.tr/PreHaberBultenleri.do?id=8642

Türkiye İstatistik Kurumu (TÜİK). (2012b). Gelir ve Yaşam Koşulları Araştırması, 2011.

T.C. Başbakanlık Türkiye İstatistik Kurumu Haber Bülteni (Sayı:10902) (17.09.2012). $\begin{array}{llllll}\text { Accessed } & \text { on } & 19 & \text { November } & 2010 & \text { from }\end{array}$ http://www.tuik.gov.tr/PreHaberBultenleri.do?id=10902

World Bank. (2001). World Development Report 2000/2001: The Nature and Evolution of Poverty. Retrieved August 14, 2012, from http://siteresources.worldbank.org/INTPOVERTY/Resources/WDR/English-Full-Text-Report /ch1.pdf

\section{Copyright Disclaimer}

Copyright reserved by the author(s).

This article is an open-access article distributed under the terms and conditions of the Creative Commons Attribution license (http://creativecommons.org/licenses/by/3.0/). 